\title{
Rail Transit Investment and Financing Mode Comparative and Matching Study
}

\author{
Qin $\mathrm{Yi}^{1,2}$ \\ 2. School of management \\ Shenyang university of technology \\ Shenyang, China \\ e-mail: qiny_cr@sut.edu.cn
}

\author{
Wang Renxiang ${ }^{1}$ \\ 1. School of economics \\ Wuhan university of technology \\ Wuhan, China \\ e-mail: Wangrx@whut.edu.cn
}

\begin{abstract}
In China, rail transit is in a rapid development stage currently. The matching between the pattern of investment and financing and the actual needs determines the construction efficiency and operation effect of the rail transit project. This article summarizes the existing models, constructs the matching model based on matter-element extension and takes Shenyang Metro as an example for study
\end{abstract}

Keywords-rail transit; investment and financing mode; matching

\section{INTRODUCTION}

Recent years, the urban rail transit shows a booming trend, which its investment and financing mode choosing determines the operating efficiency of the project. At present, China mainland urban rail transit investment and financing exists the following problems: the first one is that it is slowly for investment and financing mode to transits to the market [1]. Currently, rail transport investment and financing patterns in many cities of the mainland in China still uses a government-led debt-based investment and financing model, while though some cities adopted the market-oriented model, the proportion of social investment is still low, which is still dominated by government investment and does not really solve the funding problems of urban rail transit construction [2]. The second one is that the main investment structure is single. Now, the main construction capital resources of our mainland urban rail transit are government financial investment, commercial bank loans, foreign loans, but equity financing, issue notes, bonds, the burden on beneficiaries and other financing channels' adoption is less. Because the debt and the interest need to be repaid by the government, so the current financing channels used virtually increased the total burden of the government. The third is that the powers and responsibilities standards between government and corporate are not clear [3]. In current urban rail transit construction, the planning, financing, operation, management and other issues are not explicitly assigned someone to be responsible for it, so that sometimes there is a contradiction between the government and operators [4]. The fourth is that comprehensive development concept is not enough. Our country develops the less metro lines and subsidiary business, thereby it wastes resources above the subway. Hong Kong MTR is more successful in this respect. It fully use the space along the MTR to develop the real estate career, and this kind of concept is worthy for all of our inland urban rail transit construction departments to learn. The service objectives and functions of the different lines in different cities have a big difference, so how to take the objectives and function constrains as a carrier has become the key of successful investment patterns selection. In this paper, we adopt matter-element extension model to match the regional features, service targets and investment and financing model based on the summary of the existing models.

\section{TYPICAL COMPARISON OF RAIL INVESTMENT AND FINANCING MODEL}

Due to the high cost of urban rail transit, the long construction period and long payback period features, so that it can be provided directly by the government. The social sector can also provide by the use of market mechanisms under the conditions of government subsidies. The general theory of investment and financing think that investment and financing mainly solve the problem that who and how finance, and how to operate [5]. Coupled with of network and transport separation, the investment and financing bodies and mode of operation can realize different combinations [6].

In Wang Hao (2010) study, the combination of financing bodies and mode of operation can be summarized into five different modes: The first one is the government investment that government administrative agency is directly responsible for the project operations management; second is through the establishment of stateowned enterprises, which means the government investment by the government authorized public utilities' structure to manage and operate the project [7]. The third one is the government investment that is through invitation for bids to assign the concession contract or lease contract to entrust professional investment company and to carry out the operations. The fourth is the project financing and franchising [8]. The fifth is a diversified market-oriented financing by aiding the management of joint-stock companies. Now make a comparison of these several financing models, as shown in Table 1. 
TABLE I. TYPICAL COMPARISON OF RAIL INVESTMENT AND FINANCING MODEL

\begin{tabular}{|c|c|c|c|c|c|c|}
\hline \multirow[b]{2}{*}{ Feature } & \multicolumn{2}{|c|}{ Model A } & \multicolumn{2}{|c|}{ Model B } & \multirow[b]{2}{*}{ Model C } & \multirow[b]{2}{*}{ Model D } \\
\hline & $\begin{array}{c}\text { Government } \\
\text { Branch }\end{array}$ & $\begin{array}{c}\text { Government-owned } \\
\text { Enterprises }\end{array}$ & Lease Contract & $\begin{array}{c}\text { Concession } \\
\text { Contract }\end{array}$ & & \\
\hline $\begin{array}{l}\text { Investment and } \\
\text { Financing Body }\end{array}$ & $\begin{array}{l}\text { Government } \\
\text { Branch }\end{array}$ & $\begin{array}{l}\text { Government branch sets } \\
\text { up state-owned } \\
\text { enterprises }\end{array}$ & $\begin{array}{c}\text { Government } \\
\text { Investment } \\
\text { Public } \\
\text { Institutions and } \\
\text { Operators' } \\
\text { Negotiation }\end{array}$ & $\begin{array}{c}\text { Government } \\
\text { Investment } \\
\text { Public } \\
\text { Institutions and } \\
\text { Operators' } \\
\text { Negotiation }\end{array}$ & $\begin{array}{c}\text { Set up a } \\
\text { project } \\
\text { company } \\
\text { based on } \\
\text { social } \\
\text { capital, }\end{array}$ & $\begin{array}{c}\text { Set up a joint } \\
\text { stock company } \\
\text { through } \\
\text { diversification of } \\
\text { investments }\end{array}$ \\
\hline $\begin{array}{c}\text { Capital } \\
\text { Financing (Net) }\end{array}$ & $\begin{array}{l}\text { Government } \\
\text { Budget }\end{array}$ & $\begin{array}{c}\text { Finance and government } \\
\text { debt financing }\end{array}$ & $\begin{array}{c}\text { Financing } \\
\text { Mainly by the } \\
\text { Government }\end{array}$ & $\begin{array}{c}\text { Financing } \\
\text { Mainly by the } \\
\text { Operators Own }\end{array}$ & $\begin{array}{c}\text { Project } \\
\text { Financing }\end{array}$ & $\begin{array}{l}\text { Corporate } \\
\text { Financing }\end{array}$ \\
\hline $\begin{array}{l}\text { Recurrent } \\
\text { Financing } \\
\text { (Operations) }\end{array}$ & $\begin{array}{l}\text { Government } \\
\text { Budget }\end{array}$ & Debt financing & $\begin{array}{l}\text { Operators } \\
\text { Financing by } \\
\text { Own }\end{array}$ & $\begin{array}{c}\text { Operators } \\
\text { Financing by } \\
\text { Own }\end{array}$ & $\begin{array}{l}\text { Project } \\
\text { Financing }\end{array}$ & $\begin{array}{l}\text { Corporate } \\
\text { Financing }\end{array}$ \\
\hline $\begin{array}{l}\text { Operating and } \\
\text { Maintenance }\end{array}$ & Government & $\begin{array}{l}\text { Government-owned } \\
\text { Enterprises }\end{array}$ & Operators & Operators & $\begin{array}{l}\text { Project } \\
\text { Company }\end{array}$ & $\begin{array}{l}\text { Joint-stock } \\
\text { Company }\end{array}$ \\
\hline Stakeholders & Government & $\begin{array}{l}\text { Government-owned } \\
\text { Enterprises }\end{array}$ & Operators & Operators & $\begin{array}{c}\text { Project } \\
\text { Company }\end{array}$ & $\begin{array}{l}\text { Joint-stock } \\
\text { Company }\end{array}$ \\
\hline
\end{tabular}

Description: The first and second combination belongs to government investment and government operations (mode A), and the third one is an operation of the market under the government investment (mode B). The fourth combination is project financing and franchising (mode C). The fifth combination is the market-oriented operation mode (mode D) under a wide range of investors.

\section{RAIL TRANSIT CONSTRUCTION AND PATTERN MATCHING MODEL}

Because the chosen space is all based on the scope, therefore in order to meet this requirement, this paper selects the matter-element extension model for evaluation. Matter-element theory is to solve practical problems by establishing matter-element model. In order to accurately reflect the relationship between the quality and quantity of objects, the concept of this matter-element is put forward [9]. The concept will be able to benefit more about describing the process of object objects' change accurately. The basic unit of matter-element theory is the matterelement, which is composed of three components, namely objects, the characteristics of objects and the eigenvalues of the object [10]. Recorded as: $R=($ thing, festure, value $)=(N, c, V)$

Different objects can have same characteristics. Matter-element extension is the core issue of matterelement theory, which means the possibility changes of the object, the changes of matter-elements and the relevant researches of matter-element changes' properties. We call the two-tuples composited by characteristic $c$ and magnitude $V$ characteristic element. Recorded as: $M=(c, V)$. Characteristics of the objects, mainly includes the inherent features, like nature, status and function of the objects. Magnitude represents the measure or quantifying values of the objects characteristic [11]. The range of the amount of magnitude called domain, regarded as $V(c)$, or $V=(a, b)$, wherein, $\mathrm{a}$ and $\mathrm{b}$ on behalf of the range. If a certain object can go through multiple dimensions to represent matter-element, then each dimension elements will be expressed as $R=R(i)$, wherein $R_{i}=\left(N, c_{i}, V_{i}\right)$, $i=1,2, \ldots, n$ is called the $R$ sub-matter-element.

After determining the transformation of matterelements, we have to make the possible changes of each matter-element and evaluation of the relationships between them. The main method is to establish the basis of correlation function to describe the transformation of the objects [12]. Its basic pattern is: first define the distance between the point and interval, and then establish the correlation function according to the matter-elements, and then compute based on the correlation function and describe things' variability. The distance means the distance from the point to interval. If we assume $x$ to be any point in real domain $(-\infty,+\infty), X=(a, b)$ is the interval in real domain. Then the distance between point $x$ and interval $X$ are the formula (1) below.

$$
\rho(x, X)=\left|x-\frac{a+b}{2}\right|-\frac{1}{2}(b-a)
$$

$\rho(x, X)$ is referred to the distance between point $x$ and interval $X$. We call the distance from point $x$ to the two intervals $X_{0}=(a, b)$ and $X=(c, d)$ bit value, its relationship is shown in equation (2) below.

$$
D\left(x, X_{0}, X\right)=\left\{\begin{array}{cc}
\rho(x, X)-\rho\left(x, X_{0}\right) & x \notin X_{0} \\
-1 & x \in X_{0}
\end{array}\right\}
$$

Assuming $X_{0}=(a, b), X=(c, d)$ and $X_{0} \subset X$, then the correlation function between them shown as the formula (3) below.

$$
K(x, X)=\frac{\rho\left(x, X_{0}\right)}{D\left(x, X_{0}, X\right)}
$$

Steps of extension analysis expressed as follows:

- Establishing a system of matter-element model. Structuring classical matter-element $R$ according to the various types of structural factors' related value range on the basis of classic domain and joint domain, wherein $V_{1 i}=\left(c_{i}, d_{i}\right)$ is the limit of the possible happening values range; then according to various types of factors' tolerable ranges, we establish the element mode ${ }^{R_{0}}$ based on established joint domain. $V_{0 i}=\left(a_{i}, b_{i}\right)$ is the tolerated value ranges according to the actual companies' need.

- Establishing a correlation function to calculate the correlation degree. We establish appropriate 
correlation function according to above analysis. Meanwhile, according to the formula (1), formula (2), formula (3) to calculate, which determines the correlation function value and forms the matrix value, the matrix expressed as: $K\left(A_{n}\right)=\left(k\left(A_{1}\right), k\left(A_{2}\right) \cdots k\left(A_{n}\right)\right)^{T}$.

- Determine the weight of each evaluation factor. There are many methods to determine the weighing values of assessment factors, such as del illegal, analytic hierarchy process (AHP), of setvalued statistics, neural networks etc. Selected a evaluation method to obtain weight of each evaluation factor $M$, it's a $n$ dimensional row vector.

- Fine degree sorting calculation, because the weights of comparing conditions $V$ is $\alpha$, correlation function is matrix $K\left(A_{n}\right)$, so the fine degree sorting vector is $C\left(A_{n}\right)=M \times K\left(A_{n}\right)$, Using the vector compared the pros and cons of each solution.

\section{FinANCIAL INVESTMENT Model SELECTION OF SHENYANG ONE LINE}

This article matched investment and financing pattern of Shenyang one line, specific process is as follows:

\section{A. Establishment of index system for matching}

According to the existing research can build the index system as follows, determine the classical domain and joint domain, meanwhile, assimilate the indexes in order to avoid contradiction; afterwards, the indexes need to be normalization processed for avoiding computational problems. As the specific indicator and classical domain and joint domain is shown in table 2.

TABLE II. INDEX SYSTEM OF MATCHING

\begin{tabular}{|c|c|c|}
\hline Index & $\begin{array}{l}\text { Classical } \\
\text { Domain }\end{array}$ & $\begin{array}{c}\text { Joint } \\
\text { Domain }\end{array}$ \\
\hline $\begin{array}{l}\text { Ease of access to capital } \\
\text { in the short term }\end{array}$ & {$[0,1]$} & {$[0.6,1]$} \\
\hline $\begin{array}{l}\text { Ownership of the } \\
\text { project }\end{array}$ & {$[0,1]$} & {$[0.5,0.8]$} \\
\hline $\begin{array}{l}\text { Right of project } \\
\text { management }\end{array}$ & {$[0,1]$} & {$[0.7,1]$} \\
\hline Cost of financing & {$[0,1]$} & {$[0.7,1]$} \\
\hline $\begin{array}{l}\text { Time of project } \\
\text { financing }\end{array}$ & {$[0,1]$} & {$[0.8,1]$} \\
\hline Government risk & {$[0,1]$} & {$[0.7,1]$} \\
\hline Policy risk & {$[0,1]$} & {$[0.6,1]$} \\
\hline $\begin{array}{l}\text { Impact on the macro } \\
\text { economy }\end{array}$ & {$[0,1]$} & {$[0.5,1]$} \\
\hline Risk sharing way & {$[0,1]$} & {$[0.7,1]$} \\
\hline
\end{tabular}

\section{B. Determination of index weight}

This paper used the AHP for the determination of index weight, as specific judgment matrix and weight is shown in table 3 .

TABLE III. INDEX JUDGMENT MATRIX AND WEIGHT

\begin{tabular}{|c|c|c|c|c|c|c|c|c|c|c|}
\hline Index & C1 & C2 & C3 & C4 & C5 & C6 & C7 & C8 & C9 & Weight \\
\hline $\begin{array}{c}\text { Ease of access to capital in the short } \\
\text { term C1 }\end{array}$ & 1 & $1 / 2$ & $1 / 4$ & $1 / 6$ & 1 & $1 / 4$ & $1 / 5$ & $1 / 2$ & $1 / 6$ & 0.032 \\
\hline $\begin{array}{c}\text { Ownership of the project C2 } \\
\text { Right of project management C3 }\end{array}$ & 4 & 2 & 1 & 1 & 4 & 1 & 1 & 2 & $1 / 2$ & 0.135 \\
\hline Cost of financing C4 & 6 & 3 & 2 & 1 & 6 & 1 & 1 & 3 & 1 & 0.192 \\
\hline Time of project financing C5 & 1 & $1 / 2$ & $1 / 4$ & $1 / 6$ & 1 & $1 / 4$ & $1 / 5$ & $1 / 2$ & $1 / 6$ & 0.032 \\
\hline Government risk C6 & 4 & 2 & 1 & 1 & 4 & 1 & 1 & 2 & $1 / 2$ & 0.135 \\
\hline Policy risk C7 & 5 & 3 & 1 & 1 & 5 & 1 & 1 & $1 / 2$ & 1 & 0.144 \\
\hline Impact on the macro economy C8 & 2 & 1 & $1 / 2$ & $1 / 3$ & 2 & $1 / 2$ & $1 / 2$ & 1 & $1 / 3$ & 0.066 \\
\hline Risk sharing way C9 & 6 & 3 & 2 & 1 & 6 & 2 & 1 & 3 & 1 & 0.197 \\
\hline
\end{tabular}




\section{Calculation of priority ordering}

After an average, we can get the average value of the four models based on different experts scores of four patterns, specific see table 4 .
Using extension model for operation, results for $(0.2095,0.1868,0.2364,0.23570)$, obviously, scheme $\mathrm{C}$ is a relatively optimal solution.

TABLE IV. MEASUREMENT VALUES OF FOUR SCHEMES

\begin{tabular}{|c|c|c|c|c|}
\hline Index & Scheme A & Scheme B & Scheme C & Scheme D \\
\hline Ease of access to capital in the short term C1 & 0.8400 & 0.8895 & 0.9763 & 0.6061 \\
\hline Ownership of the project C2 & 0.7773 & 0.6623 & 0.6134 & 0.7290 \\
\hline Right of project management C3 & 0.6580 & 0.6218 & 0.7668 & 0.6808 \\
\hline Cost of financing C4 & 0.7314 & 0.8947 & 0.7373 & 0.7757 \\
\hline Time of project financing C5 & 0.9286 & 0.8715 & 0.9701 & 0.7319 \\
\hline Government risk C6 & 0.9092 & 0.8134 & 0.7380 & 0.9125 \\
\hline Policy risk C7 & 0.9261 & 0.8019 & 0.8804 & 0.6912 \\
\hline Impact on the macro economy C8 & 0.7856 & 0.9386 & 0.6419 & 0.7314 \\
\hline
\end{tabular}

\section{CONCLUSION}

This paper first divided investment and financing mode into several categories, namely, government agencies responsible for manage the project operator directly, government invest to establish wholly stateowned enterprises for operation and management of government investment project; franchise or rental operates to entrust professional company for government investment; and the diversified market financing model that joint stock company manage and operate. Afterwards, constructed matter-element extension model used to match between Shenyang one line and the choice of investment and financing model.

\section{REFERENCES}

[1] Beaver, The rail promotes the development, constructs the integrated traffic system, word railway, 2005, pp. 271-350.

[2] Sock-yong phang. Urban mass traban mass teansit ppps: Survey and risk assessment of recent strategies. Transport policy, 2007, pp. 57-64.

[3] J. J. Buckley, T. Feuring, Y. Hayashi. Solving fuzzy problems in operations research: inventory control. Soft Computing, 2002, pp. 123-131.
[4] Yasushi H, Frank P, Jay R. Institutional affiliation and the role of venture capital evidence from initial public offering in Japan. Pacific-Basin,2000, pp. 231-243.

[5] Michael Gannon and Shawn Neidorf. Larger Ventrue capital Funds Spawn Bigger Deals as US Boom Continues. European Venture Capital Journal, 1999, pp. 341-349.

[6] Jugren Ronald K. Nvaigation and intelligent transportation systems, Society of Automotive Engineer, 1998, pp. 94-105.

[7] Sungmin Yun, Seung Heon Han, Hyoungkwan Kim, Jong Ho Ock. Capital structure optimization for build-operate-transfer (BOT) projects using a stochastic and multi-objective approach. Can. J. Civ. Eng. Vol. 74, Dec. 2009, pp. 777-790.

[8] Veronika Sabolova, Libena Tetrevova. Alternative forms of financing PPP projects. Business and management, 2010, pp. 176185.

[9] Jen-Jia Lin, Chi-Hau Hwang. Analysis of Property Prices before and after the opening of the Taipei subway system. The Annals of Regional Science, 2004, pp. 687-704.

[10] James W. Tvancs, Lilliam. Lindsay. The Management and Control Quality. Cincinnati: Sout-Weatern Publishing, 2002, pp. 110-132.

[11] Lieb R, Randall H.CEO perspectives on the current status and future prospects of the third Party logistics industry in the United States. Transportation logistics, 1996, pp. 51-66.

[12] D, M. Lambert, A. E. Margaret, T. G. John. Building Successful Logistics Partnerships. Journal of Business Logistics, 1999, pp. 165-181. 